\title{
Surfactant Protein D, Soluble Intercellular Adhesion Molecule-1 and High-Sensitivity C-Reactive Protein as Biomarkers of Chronic Obstructive Pulmonary Disease
}

\author{
Sahar E. El-Deek ${ }^{a}$ Hoda A. Makhlouf ${ }^{b}$ Tahia H. Saleem ${ }^{a}$ Manal A. Mandour ${ }^{a}$ \\ Nahed A. Mohamed ${ }^{\text {}}$ \\ Departments of ${ }^{a}$ Medical Biochemistry and ${ }^{b}$ Chest Diseases, Faculty of Medicine, Assiut University, Assiut, Egypt
}

\section{Key Words \\ Chronic obstructive pulmonary disease - Surfactant protein D . Soluble intercellular adhesion molecule-1 . \\ High-sensitivity C-reactive protein}

\begin{abstract}
Objective: The aim of this study was to estimate the serum levels of surfactant protein D (SP-D), soluble intercellular adhesion molecule-1 (sICAM-1), and high-sensitivity C-reactive protein (hs-CRP) in patients with chronic obstructive pulmonary disease (COPD) and to assess the correlation of these indices with COPD severity. Subjects and Methods: This analytic cross-sectional study was carried out on 64 COPD male patients, and 26 apparently healthy age-matched males as a control. Chest X-ray, spirometry and arterial blood gases were done for only COPD patients. Serum levels of SP-D, sICAM-1 and hs-CRP were determined by enzyme-linked immunosorbent assay in both patient and control groups. Results: The serum levels of SP-D, sICAM-1 and hs-CRP were significantly higher in COPD patients than controls $(p<0.001$ for each). Also, these biomarkers were significantly higher
\end{abstract}

in stages III and IV compared to either stage I or II ( $p<0.01$ for each). SP-D was significantly positively correlated with sICAM-1 and hs-CRP ( $r=515, p<0.001 ; r=501, p<0.001$, respectively) and negatively correlated with $\mathrm{PaO}_{2}(r=-0.651$, $p<0.001)$ and all parameters of spirometry. Conclusion: SP$D$, sICAM and hs-CRP were significantly higher in COPD patients in comparison with controls. Moreover, SP-D, sICAM-1, and hs-CRP were significantly negatively correlated with $\mathrm{FEV}_{1} \%$. Accordingly, estimation of these biochemical indices may be used as biomarkers for assessment of COPD severity.

Copyright $\odot 2013$ S. Karger AG, Basel

\section{Introduction}

Chronic obstructive pulmonary disease (COPD) is a leading cause of morbidity and mortality $[1,2]$. Tobacco smoking is considered the primary cause and the major risk factor for development of COPD. The prevalence of COPD is reported to be on the increase in most of the industrialized countries [3]. In Egypt, the prevalence of COPD is approximately $1.1 \%[4]$.

Dr. Hoda A. Makhlouf

Department of Chest Diseases, Faculty of Medicine, Assiut University Assiut University Hospital

Assiut 71111 (Egypt)

E-Mail hamakhlouf@yahoo.com 
Table 1. Demographic data of the study group

\begin{tabular}{|c|c|c|c|c|c|}
\hline \multirow[t]{2}{*}{ Variable } & \multirow{2}{*}{$\begin{array}{l}\text { Control } \\
(n=26)\end{array}$} & \multicolumn{4}{|c|}{ Patients with COPD } \\
\hline & & $\begin{array}{l}\text { stage I } \\
(\mathrm{n}=10)\end{array}$ & $\begin{array}{l}\text { stage II } \\
(\mathrm{n}=17)\end{array}$ & $\begin{array}{l}\text { stage III } \\
(\mathrm{n}=17)\end{array}$ & $\begin{array}{l}\text { stage IV } \\
(\mathrm{n}=20)\end{array}$ \\
\hline Age, years & $57.96 \pm 7.09$ & $53.9 \pm 8.45$ & $59.0 \pm 11.55$ & $64.18 \pm 6.11$ & $59.5 \pm 7.16$ \\
\hline \multicolumn{6}{|l|}{ Smoking habits } \\
\hline Smokers & $14(53.8 \%)$ & $10(100 \%)$ & $17(100 \%)$ & $17(100 \%)$ & $20(100 \%)$ \\
\hline Nonsmokers & $12(46.2 \%)$ & $0(0 \%)$ & $0(0 \%)$ & $0(0 \%)$ & $0(0 \%)$ \\
\hline \multicolumn{6}{|l|}{ Symptoms } \\
\hline Cough & & $10(100 \%)$ & $17(100 \%)$ & $17(100 \%)$ & $20(100 \%)$ \\
\hline Expectoration & & $9(90 \%)$ & $17(100 \%)$ & $17(100 \%)$ & $17(100 \%)$ \\
\hline Dyspnea & & $10(100 \%)$ & $17(100 \%)$ & $17(100 \%)$ & $20(100 \%)$ \\
\hline Chest wheezes & & $8(80 \%)^{*}$ & $7(41.2)$ & $0(0 \%)$ & $0(0 \%)$ \\
\hline
\end{tabular}

Pulmonary surfactant is a complex material that covers the alveolar surface of the lung; it reduces the surface tension at the air-liquid interface of the alveoli, thereby preventing alveolar collapse during expiration [5]. Surfactant protein D (SP-D) is a large hydrophilic, multimeric, collagenous glycoprotein that belongs to the family of collectins, which is a subgroup of C-type lectins. When lung injury occurs, SP-D may leak out from the lung compartment into the systemic circulation and can be detected in serum [6]. Cell adhesion molecules are defined as proteins located on the surface of the cell and involved with the binding with other cells or with the extracellular matrix called cell adhesion [7]. Soluble intercellular adhesion molecule-1 (sICAM-1) is expressed on vascular endothelium and on immune and inflammatory cells. It mediates the adhesion and transmigration of leukocytes to vascular endothelium [8]. The up-regulation of sICAM-1 in COPD remains uncertain because of conflicting findings [911 .

High-sensitivity C-reactive protein (hs-CRP) is an acute-phase protein, which is strongly linked to airway inflammation and obstruction [12]. Elevated CRP has been used as a predictor of adverse events in pulmonary and cardiovascular diseases and as a marker of systemic inflammation in diverse conditions [13].

The objectives of this study were to estimate the serum levels of SP-D, sICAM-1, and hs-CRP in patients with COPD and the correlation of their serum levels with the severity of COPD as measured by pulmonary function tests.

\section{Subjects and Methods}

This analytic cross-sectional study was carried out on 64 COPD male patients who were selected from the Outpatient Clinic of the Department of Chest Diseases at Assiut University Hospital, Egypt. The patients with COPD were diagnosed and classified according to the Global Initiative for Chronic Obstructive Lung Disease (GOLD, 2007) [2]. In addition, 26 apparently healthy, ageand sex-matched individuals were included in this study as a control group. The control group was subclassified into nonsmokers $(\mathrm{n}=14)$ and smokers $(\mathrm{n}=12)$. Informed written consent was obtained from each subject and the study was approved by the Faculty of Medicine Ethics Committee, Assiut University, Egypt.

The following patients were excluded: patients who had other respiratory diseases, associated hepatic or renal diseases, recent surgery and malignancy and COPD exacerbation within 4 weeks of the study.

All the enrolled participants had their medical history taken, physical examination and chest X-ray. The diagnosis of COPD was made on the basis of clinical and radiological criteria, followed by spirometry (ZAN300, Oberthulba, Germany). Arterial blood gases in room air were obtained by blood sampling from a radial artery and analyzed using a blood gas analyzer (Rapid Lab 850; Chiron Diagnostics, Critical Care Systems). A 10-ml sample of venous blood was collected from both patient and control groups by venipuncture under completely aseptic conditions. The samples were collected in plain tubes and were allowed to clot at room temperature for at least $30 \mathrm{~min}$, then centrifuged at 1,500 rpm for $15 \mathrm{~min}$ at room temperature. The serum was divided into three aliquots using a sterile plastic transfer pipette and frozen in $-70^{\circ} \mathrm{C}$ until use. Serum SP-D was determined by using a Surfactant Protein D Human ELISA kit (BioVendor Laboratorni Medicina) according to the method described by Crouch [14]. The minimum detectable level and the intra-assay and interassay coefficients of the serum SP-D test were $0.2 \mathrm{ng} / \mathrm{ml}, 3.7$ and $7.5 \%$, respectively. Serum sICAM-1 was determined by using a Human sICAM-1 ELISA kit (Bender MedSystems GmbH, Campus Vienna Biocenter) accord- 
ing to the methods described by Adams et al. [15]. The minimum detectable level and the intra-assay and interassay coefficients of the serum sICAM-1 test were $2.2 \mathrm{ng} / \mathrm{ml}, 4.1$ and $7.7 \%$, respectively. Serum hs-CRP was determined by using an ELISA kit (Diagnostics Biochem, Canada), according to the methods described by Roberts et al. [16]. The minimum detectable level and the intraassay and interassay coefficients of the serum hs-CRP test were $10 \mathrm{ng} / \mathrm{ml}, 8.3 \%$, and $9.5 \%$, respectively.

\section{Statistical Analysis}

Statistical analysis was performed using the Statistical Package for the Social Sciences (SPSS version 17) software. The results are expressed as means \pm standard deviation or frequencies. One-way ANOVA was used for comparison of continuous variables between the four stages of COPD. Independent Student's $t$ test was done for comparison between COPD and controls. Proportions were compared using $\chi^{2}$ tests. Pearson's correlation analysis was used to evaluate the correlations between different parameters in each group; $\mathrm{p}$ values $<0.05$ were considered significant. The threshold value for optimal sensitivity and specificity of the SP-D was determined by the receiver operating characteristics (ROC) curve.

\section{Results}

The demographic data are shown in table 1. Pulmonary function tests in stages III or IV were significantly lower than either in stage I or II ( $p<0.001$ for each). Moreover, $\mathrm{FEV}_{1}$ liters/s, $\mathrm{FEV}_{1} \%$ and $\mathrm{FVC} \%$ in stage IV were significantly lower than those in stage III ( $p=0.009$, $\mathrm{p}<0.001, \mathrm{p}=0.002$, table 2). Regarding the arterial blood gases, $\mathrm{PaO}_{2}$ and $\mathrm{O}_{2}$ saturation ( $\mathrm{p}<0.001$ for each) were significantly lower; $\mathrm{PaCO}_{2}$ and $\mathrm{HCO}_{3}$ were significantly higher in stage IV compared to stage I ( $p<0.001)$, II ( $p<$ $0.001)$ or III ( $\mathrm{p}=0.004, \mathrm{p}=0.001$, table 2$)$.

The serum levels of SP-D were significantly higher in COPD patients $(314.8 \pm 103.0)$ than in controls $(1,228 \pm$ $31.9 \mathrm{ng} / \mathrm{ml}, \mathrm{p}<0.001)$. The SP-D levels in stages II, III and IV were significantly higher than those of controls (both nonsmokers and smokers, $\mathrm{p}<0.001$ for each), and also, in stage I compared to control nonsmokers or control smokers ( $\mathrm{p}<0.001$ and $\mathrm{p}=0.021$, respectively). Moreover, significantly higher SP-D levels were observed in stages III and IV compared to either stage I or II ( $p<0.001$ for each). Also, there were significantly higher SP-D levels compared to stage III ( $\mathrm{p}=0.003$, table 3$)$.

Serum levels of sICAM-1 were significantly higher in COPD patients than in the control group (148.4 \pm 39.7 vs. $101.7 \pm 2.8 \mathrm{ng} / \mathrm{ml}, \mathrm{p}<0.001)$. A significantly higher mean level of sICAM-1 was noticed in stages III and IV compared to either controls (both nonsmokers and smokers), stage I or stage II ( $\mathrm{p}<0.001$ for each), and in stage II compared to control nonsmokers $(\mathrm{p}=0.029$, table 3$)$.
Table 2. Pulmonary function tests and arterial blood gases of COPD patients

\begin{tabular}{|c|c|c|c|c|}
\hline Variable & $\begin{array}{l}\text { Stage I } \\
(\mathrm{n}=10)\end{array}$ & $\begin{array}{l}\text { Stage II } \\
(\mathrm{n}=17)\end{array}$ & $\begin{array}{l}\text { Stage III } \\
(\mathrm{n}=17)\end{array}$ & $\begin{array}{l}\text { Stage IV } \\
(\mathrm{n}=20)\end{array}$ \\
\hline \multicolumn{5}{|c|}{ Pulmonary function tests } \\
\hline $\begin{array}{l}\mathrm{FEV}_{1} \text {, liters/s } \\
\text { p1 } \\
\text { p2 } \\
\text { p3 }\end{array}$ & $2.83 \pm 0.22$ & $\begin{array}{l}1.9 \pm 0.45 \\
<0.001^{*}\end{array}$ & $\begin{array}{l}0.98 \pm 0.29 \\
<0.001^{*} \\
<0.001^{*}\end{array}$ & $\begin{array}{l}0.72 \pm 0.13 \\
<0.001^{*} \\
<0.001^{*} \\
0.009^{*}\end{array}$ \\
\hline $\begin{array}{l}\mathrm{FEV}_{1}, \% \\
\text { p1 } \\
\text { p2 } \\
\text { p3 }\end{array}$ & $81.7 \pm 2.31$ & $\begin{array}{l}64.41 \pm 6.21 \\
<0.001^{*}\end{array}$ & $\begin{array}{l}37.12 \pm 5.78 \\
<0.001^{*} \\
<0.001^{*}\end{array}$ & $\begin{array}{l}25.45 \pm 4.21 \\
<0.001^{*} \\
<0.001^{*} \\
<0.001^{*}\end{array}$ \\
\hline $\begin{array}{l}\text { FVC, liters/s } \\
\text { p1 } \\
\text { p2 } \\
\text { p3 }\end{array}$ & $4.80 \pm 0.58$ & $\begin{array}{l}3.23 \pm 0.78 \\
<0.001^{*}\end{array}$ & $\begin{array}{l}2.17 \pm 0.63 \\
<0.001^{*} \\
<0.001^{*}\end{array}$ & $\begin{array}{l}1.78 \pm 0.43 \\
<0.001^{*} \\
<0.001^{*} \\
0.058\end{array}$ \\
\hline $\begin{array}{l}\text { FVC, } \% \\
\text { p1 } \\
\text { p2 } \\
\text { p3 }\end{array}$ & $113.8 \pm 12.66$ & $\begin{array}{l}87.06 \pm 12.23 \\
<0.001^{*}\end{array}$ & $\begin{array}{l}63.47 \pm 15.22 \\
<0.001^{*} \\
<0.001^{*}\end{array}$ & $\begin{array}{l}50.3 \pm 9.85 \\
<0.001^{*} \\
<0.001^{*} \\
0.002^{*}\end{array}$ \\
\hline $\begin{array}{l}\mathrm{FEV}_{1} / \mathrm{FVC} \% \\
\text { p1 } \\
\text { p2 } \\
\text { p3 }\end{array}$ & $59.42 \pm 6.08$ & $\begin{array}{l}59.71 \pm 9.04 \\
0.917\end{array}$ & $\begin{array}{l}45.44 \pm 4.68 \\
<0.001^{*} \\
<0.001^{*}\end{array}$ & $\begin{array}{c}41.2 \pm 6.68 \\
<0.001^{*} \\
<0.001^{*} \\
0.066\end{array}$ \\
\hline $\begin{array}{l}\mathrm{FEF}_{25-75}, \text { liters/s } \\
\text { p1 } \\
\text { p2 } \\
\text { p3 }\end{array}$ & $1.95 \pm 0.52$ & $\begin{array}{l}1.14 \pm 0.51 \\
<0.001^{*}\end{array}$ & $\begin{array}{l}0.42 \pm 0.14 \\
<0.001^{*} \\
<0.001^{*}\end{array}$ & $\begin{array}{l}0.29 \pm 0.05 \\
<0.001 \\
<0.001 \\
0.264\end{array}$ \\
\hline $\begin{array}{c}\mathrm{FEF}_{25-75}, \% \\
\text { p1 } \\
\text { p2 } \\
\text { p3 }\end{array}$ & $48.6 \pm 11.35$ & $\begin{array}{l}33 \pm 10.64 \\
<0.001^{*}\end{array}$ & $\begin{array}{l}13.59 \pm 3.43 \\
<0.001^{*} \\
<0.001^{*}\end{array}$ & $\begin{array}{l}8.9 \pm 1.48 \\
0.000^{*} \\
0.000^{*} \\
0.056\end{array}$ \\
\hline
\end{tabular}

\begin{tabular}{|c|c|c|c|c|}
\hline \multicolumn{5}{|c|}{ Arterial blood gases } \\
\hline $\begin{array}{l}\mathrm{PaO}_{2}, \mathrm{~mm} \mathrm{Hg} \\
\text { p1 } \\
\text { p2 } \\
\text { p3 }\end{array}$ & $92.4 \pm 6.36$ & $\begin{array}{l}89.65 \pm 6.26 \\
0.452\end{array}$ & $\begin{array}{l}76.94 \pm 7.76 \\
<0.001^{*} \\
<0.001^{*}\end{array}$ & $\begin{array}{l}60.95 \pm 12.67 \\
<0.001^{*} \\
<0.001^{*} \\
<0.001^{*}\end{array}$ \\
\hline $\begin{array}{l}\mathrm{PaCO}_{2}, \mathrm{~mm} \mathrm{Hg} \\
\text { p1 } \\
\text { p2 } \\
\text { p3 }\end{array}$ & $30.04 \pm 4.8$ & $\begin{array}{l}34.84 \pm 4.08 \\
0.211\end{array}$ & $\begin{array}{l}42.62 \pm 5.98 \\
0.002^{*} \\
0.020^{*}\end{array}$ & $\begin{array}{l}52.14 \pm 15.22 \\
<0.001^{*} \\
<0.001^{*} \\
0.004^{*}\end{array}$ \\
\hline $\begin{array}{l}\mathrm{pH} \\
\mathrm{p} 1 \\
\mathrm{p} 2 \\
\mathrm{p} 3\end{array}$ & $7.44 \pm 0.03$ & $\begin{array}{l}7.42 \pm 0.04 \\
0.315\end{array}$ & $\begin{array}{l}7.41 \pm 0.07 \\
0.168 \\
0.658\end{array}$ & $\begin{array}{l}7.42 \pm 0.05 \\
0.452 \\
0.739 \\
0.429\end{array}$ \\
\hline $\begin{array}{c}\mathrm{HCO}_{3}, \mathrm{mmol} / \mathrm{l} \\
\text { p1 } \\
\text { p2 } \\
\text { p3 }\end{array}$ & $21.09 \pm 4.08$ & $\begin{array}{l}24.17 \pm 3.66 \\
0.140\end{array}$ & $\begin{array}{c}29.15 \pm 4.26 \\
<0.001^{*} \\
0.007^{*}\end{array}$ & $\begin{array}{l}35.15 \pm 7.05 \\
<0.001^{*} \\
<0.001^{*} \\
0.001^{*}\end{array}$ \\
\hline $\begin{array}{c}\mathrm{O}_{2} \text { Sat, \% } \\
\text { p1 } \\
\text { p2 } \\
\text { p3 }\end{array}$ & $97.54 \pm 0.71$ & $\begin{array}{l}95.57 \pm 5.85 \\
0.373\end{array}$ & $\begin{array}{l}95.42 \pm 3.59 \\
0.337 \\
0.936\end{array}$ & $\begin{array}{l}88.32 \pm 7.47 \\
<0.001^{*} \\
<0.001^{*} \\
<0.001^{*}\end{array}$ \\
\hline
\end{tabular}

$\mathrm{FEV}_{1}=$ Forced expiratory volume in $1 \mathrm{~s} ; \mathrm{FVC}=$ forced vital capacity; $\mathrm{FEF}=$ forced expiratory flow; $\mathrm{PaO}_{2}=$ arterial partial pressure of oxygen; $\mathrm{PaCO}_{2}=$ arterial partial pressure of carbon dioxide; $\mathrm{HCO}_{3}=$ bicarbonate; $\mathrm{O}_{2}$ Sat $=\mathrm{O}_{2}$ saturation; $\mathrm{p} 1$ = versus stage I; $\mathrm{p} 2=$ versus stage II; $\mathrm{p} 3=$ versus stage III. Data expressed as mean $\pm \mathrm{SD}$; $\mathrm{p}$ values with an asterisk are significant. 
Table 3. Mean serum levels of SP-D, sICAM-1 and hs-CRP in patients with COPD and controls

\begin{tabular}{|c|c|c|c|c|c|c|}
\hline \multirow[t]{2}{*}{ Groups/variables } & \multicolumn{2}{|l|}{ Control $(n=26)$} & \multicolumn{4}{|c|}{ COPD patients $(n=64)$} \\
\hline & $\begin{array}{l}\text { control nonsmokers } \\
(\mathrm{n}=12)\end{array}$ & $\begin{array}{l}\text { control smokers } \\
(\mathrm{n}=14)\end{array}$ & $\begin{array}{l}\text { stage I } \\
(\mathrm{n}=10)\end{array}$ & $\begin{array}{l}\text { stage II } \\
(\mathrm{n}=17)\end{array}$ & $\begin{array}{l}\text { stage III } \\
(\mathrm{n}=17)\end{array}$ & $\begin{array}{l}\text { stage IV } \\
(\mathrm{n}=20)\end{array}$ \\
\hline $\begin{array}{l}\text { SP-D, ng/ml } \\
\text { p1 } \\
\text { p2 } \\
\text { p3 } \\
\text { p4 } \\
\text { p5 }\end{array}$ & $97.45 \pm 14.21$ & $\begin{array}{l}144.44 \pm 26.14 \\
0.038^{*}\end{array}$ & $\begin{array}{l}199.63 \pm 45.18 \\
<0.001^{*} \\
0.021^{*}\end{array}$ & $\begin{array}{l}241.29 \pm 42.72 \\
<0.001^{*} \\
<0.001^{*} \\
0.068\end{array}$ & $\begin{array}{l}348.59 \pm 77.22 \\
<0.001^{*} \\
<0.001^{*} \\
<0.001^{*} \\
<0.001^{*}\end{array}$ & $\begin{array}{l}406.01 \pm 77.89 \\
<0.001^{*} \\
<0.001^{*} \\
<0.001^{*} \\
<0.001^{*} \\
0.003^{*}\end{array}$ \\
\hline $\begin{array}{l}\text { sICAM-1, ng/ml } \\
\text { p1 } \\
\text { p2 } \\
\text { p3 } \\
\text { p4 } \\
\text { p5 }\end{array}$ & $99.65 \pm 2.36$ & $\begin{array}{l}103.42 \pm 1.66 \\
0.714\end{array}$ & $\begin{array}{l}116.55 \pm 16.60 \\
0.244 \\
0.148\end{array}$ & $\begin{array}{l}122.36 \pm 9.08 \\
0.029^{*} \\
0.056\end{array}$ & $\begin{array}{l}163.74 \pm 46.29 \\
<0.001^{*} \\
<0.001^{*} \\
<0.001^{*} \\
<0.001^{*}\end{array}$ & $\begin{array}{l}173.38 \pm 34.92 \\
<0.001^{*} \\
<0.001^{*} \\
<0.001^{*} \\
<0.001^{*} \\
0.382\end{array}$ \\
\hline
\end{tabular}

p1 = vs. control nonsmokers; p2 = vs. control smokers; p3 = vs. stage I; p4 = vs. stage II; p5 = vs. stage III. Data are expressed as mean $\pm \mathrm{SD}$; $\mathrm{p}$ values with an asterisk are significant.

There was a significantly higher serum level of hs-CRP in COPD patients compared to the control group $(5,666.6 \pm 853.6$ vs. $4,027.0 \pm 707.4 \mathrm{ng} / \mathrm{ml}, \mathrm{p}<0.001)$. Also, the hs-CRP levels were significantly higher in stages I-IV in comparison with control nonsmokers ( $p<0.001$ for each), and also in stages II-IV compared to control smokers $(\mathrm{p}=0.001, \mathrm{p}<0.001$ and $\mathrm{p}<0.001$, respectively) and in control smokers compared to control nonsmokers $(\mathrm{p}=0.005)$. Significantly higher hs-CRP levels in stages III and IV compared to either stage I $(\mathrm{p}<0.001)$ or II ( $\mathrm{p}=$ $0.003, \mathrm{p}<0.001$, table 3).

There were significantly negative correlations between serum levels of SP-D, sICAM-1, and hs-CRP with all parameters of pulmonary function tests including $\mathrm{FEV}_{1} \%(\mathrm{p}<0.001)$. Serum levels of SP-D, sICAM-1, and hs-CRP were significantly negatively correlated with $\mathrm{PaO}_{2}(\mathrm{p}<0.001)$ and significantly positively correlated with $\mathrm{PaCO}_{2}(\mathrm{p}<0.001 ; \mathrm{p}=0.006 ; \mathrm{p}=0.004)$ and $\mathrm{HCO}_{3}{ }^{-}(\mathrm{p}<0.001, \mathrm{p}<0.001, \mathrm{p}<0.001$, table 4$)$. There were significant positive correlations between SP-D and sICAM-1 $(\mathrm{r}=515, \mathrm{p}<0.001)$, and SP-D and hs-CRP $(\mathrm{r}=$ $501, p<0.001)$. Using the ROC curve of serum SP-D, the best cutoff value was $186.14 \mathrm{ng} / \mathrm{ml}$; sensitivity was $90.60 \%$, specificity $100 \%$, and area under the ROC curve 0.954 .

\section{Discussion}

In the current study, the mean serum levels of SP-D were significantly higher in COPD patients compared to the control group. The SP-D levels in stages III and IV were significantly higher than in other stages. Moreover, the SP-D levels in control smokers were significantly higher than in control nonsmokers. In addition, there were significantly negative correlations between serum levels of SP-D with pulmonary function tests including $\mathrm{FEV}_{1} \%$ and $\mathrm{PaO}_{2}$ and significantly positive correlation with $\mathrm{PaCO}_{2}$. These data suggest that elevated serum SP-D is a good marker of reduced lung function and thus serum SP-D is a promising biomarker for tracking COPD progression.

These results are in agreement with previous studies 1 $[17,18]$ that reported overexpression of SP-D in patients with COPD. In concordance to our study, Laniado-Labo- 
Table 4. Correlation coefficients of various markers studied, pulmonary function tests and arterial blood gases of COPD patients

\begin{tabular}{|c|c|c|c|}
\hline Variable & SP-D & sICAM-1 & hs-CRP \\
\hline \multicolumn{4}{|c|}{ Pulmonary function tests } \\
\hline \multicolumn{4}{|c|}{$\mathrm{FEV}_{1}$, liters/s } \\
\hline $\mathrm{r}$ & -0.727 & -0.541 & -0.541 \\
\hline $\mathrm{p}$ value & $<0.001^{*}$ & $<0.001^{*}$ & $<0.001^{*}$ \\
\hline \multicolumn{4}{|l|}{$\mathrm{FEV}_{1}, \%$} \\
\hline $\mathrm{r}$ & -0.775 & -0.577 & -0.590 \\
\hline $\mathrm{p}$ value & $<0.001^{*}$ & $<0.001^{*}$ & $<0.001^{*}$ \\
\hline \multicolumn{4}{|c|}{ FVC, liters/s } \\
\hline $\mathrm{r}$ & -0.714 & -0.492 & -0.481 \\
\hline $\mathrm{p}$ value & $<0.001^{*}$ & $<0.001^{*}$ & $<0.001^{*}$ \\
\hline \multicolumn{4}{|l|}{ FVC, $\%$} \\
\hline $\mathrm{r}$ & -0.759 & -0.485 & -0.508 \\
\hline p value & $<0.001^{*}$ & $<0.001^{*}$ & $<0.001^{*}$ \\
\hline \multicolumn{4}{|c|}{$\mathrm{FEV}_{1} / \mathrm{FVC}^{2}$} \\
\hline $\mathrm{r}$ & -0.528 & -0.465 & -0.481 \\
\hline $\mathrm{p}$ value & $<0.001^{*}$ & $<0.001^{*}$ & $<0.001^{*}$ \\
\hline \multicolumn{4}{|c|}{$\mathrm{FEF}_{25-75}$, liters/s } \\
\hline $\mathrm{r}$ & -0.666 & -0.486 & -0.466 \\
\hline $\mathrm{p}$ value & $<0.001^{*}$ & $<0.001^{*}$ & $<0.001^{*}$ \\
\hline \multicolumn{4}{|l|}{$\mathrm{FEF}_{25-75}, \%$} \\
\hline $\mathrm{r}$ & -0.711 & -0.521 & -0.472 \\
\hline $\mathrm{p}$ value & $<0.001^{*}$ & $<0.001^{*}$ & $<0.001^{*}$ \\
\hline \multicolumn{4}{|c|}{ Arterial blood gases } \\
\hline \multicolumn{4}{|c|}{$\mathrm{PaO}_{2}, \mathrm{~mm} \mathrm{Hg}^{\circ}$} \\
\hline $\mathrm{r}$ & -0.651 & -0.538 & -0.545 \\
\hline $\mathrm{p}$ value & $<0.001^{*}$ & $<0.001^{*}$ & $<0.001^{*}$ \\
\hline \multicolumn{4}{|c|}{$\mathrm{PaCO}_{2}, \mathrm{~mm} \mathrm{Hg}$} \\
\hline $\mathrm{r}$ & 0.597 & 0.341 & 0.356 \\
\hline $\mathrm{p}$ value & $<0.001^{*}$ & $<0.006^{*}$ & $0.004^{*}$ \\
\hline \multicolumn{4}{|l|}{$\mathrm{pH}$} \\
\hline$r$ & -0.114 & 0.018 & 0.143 \\
\hline $\mathrm{p}$ value & 0.371 & 0.888 & 0.259 \\
\hline \multicolumn{4}{|c|}{$\mathrm{HCO}_{3}^{-}, \mathrm{mmol} / \mathrm{l}$} \\
\hline $\mathrm{r}$ & 0.593 & 0.450 & 0.453 \\
\hline $\mathrm{p}$ value & $<0.001^{*}$ & $<0.001^{*}$ & $<0.001^{*}$ \\
\hline \multicolumn{4}{|l|}{$\mathrm{O}_{2}$ Sat, $\%$} \\
\hline $\mathrm{r}$ & -0.406 & -0.342 & -0.220 \\
\hline $\mathrm{p}$ value & $0.001^{*}$ & $0.006^{*}$ & 0.081 \\
\hline
\end{tabular}

$\mathrm{FEV}_{1}=$ Forced expiratory volume in $1 \mathrm{~s} ; \mathrm{FVC}=$ forced vital capacity; $\mathrm{FEF}=$ forced expiratory flow; $\mathrm{PaO}_{2}=$ arterial partial pressure of oxygen; $\mathrm{PaCO}_{2}=$ arterial partial pressure of carbon dioxide; $\mathrm{HCO}_{3}=$ bicarbonate; $\mathrm{O}_{2}$ Sat $=\mathrm{O}_{2}$ saturation; $\mathrm{r}=$ correlation coefficient; $\mathrm{p}$ values with an asterisk are significant.

rin [19] and Lomas et al. [6] detected a difference in serum SP-D between smokers and nonsmokers. Moreover, Sin et al. [20] found that SP-D was significantly inversely correlated with pulmonary function tests including $\mathrm{FEV}_{1}$, which is in agreement with the present study. In addition, Ju et al. [21] concluded that SP-D can reflect the overall
COPD severity. On the other hand, Cazzola and Novelli [22] demonstrated that serum SP-D levels were not associated with COPD severity as defined by the GOLD status.

The following findings confirmed previous studies: serum sICAM-1 levels were higher in COPD patients as compared to control groups, in stages III and IV as compared to other groups, and had significantly negative correlation with pulmonary function tests and $\mathrm{PaO}_{2}$ and a significantly positive correlation with $\mathrm{PaCO}_{2}[10,11,23]$. sICAM- 1 is important in the recruitment and migration of leukocytes from the circulation to inflammatory tissues [8].

Hs-CRP is an acute-phase protein, which plays a pathogenic role in airway inflammation [12]. In the current study, the mean serum levels of hs-CRP were significantly higher in COPD patients compared to the control group and in stages III and IV compared to other groups. Also, the mean serum levels of hs-CRP were significantly higher in control smokers compared to control nonsmokers. There was a significantly negative correlation between hs-CRP and pulmonary function tests and $\mathrm{PaO}_{2}$. These results were in agreement with previous studies [24-27]. The finding that hs-CRP was significantly positively correlated with sICAM-1 confirmed the study by Walter et al. [28]. This may be due to the effects of cigarette smoking, which confirms the role of systemic inflammation in the pathogenesis of COPD.

There are some limitations to this study. First, the sample size is not large. Second, being a cross-sectional study, we cannot take into account the temporal sequence of events, i.e. it cannot be determined whether the exposure preceded the measured outcome. Third, it is not a followup study, thus remote effects could not be studied. Fourth, we did not do multivariable analysis in this study.

\section{Conclusion}

SP-D, sICAM-1 and hs-CRP were significantly higher in COPD patients in comparison with controls. Moreover, SP-D, sICAM-1, and hs-CRP were significantly negatively correlated with $\mathrm{FEV}_{1} \%$. Accordingly, estimates of these biochemical indices may be used as biomarkers for the assessment of COPD severity.

\section{Acknowledgments}

The authors thank all the nursing staff in the Chest Outpatient Clinic and the technicians in the Medical Biochemistry Laboratory, Assiut University Hospital, Egypt, for their help during the study period. 


\section{References}

$>1$ Cosio M, Saetta M, Agusti A: Immunologic aspects of chronic obstructive pulmonary disease. N Engl J Med 2009;360:2445-2454.

2 Global Initiative for Chronic Obstructive Lung Disease: Global strategy for the Diagnosis, Management and Prevention of Chronic Obstructive Lung Disease (updated 2007). Available from http://www.goldcopd.org.

-3 Winkler C, Atochina-Vasserman E, Holz O, et al: Comprehensive characterization of pulmonary and serum surfactant protein D in COPD. Respir Res 2011;12:29-40.

4 WHO Global Infobase: Country Profile of Environmental Burden of Disease. Geneva, WHO, Public Health and the Environment, 2009, 1-7.

5 Kierstein S, Poulain F, Cao Y: Susceptibility to ozone-induced airway inflammation is associated with decreased levels of surfactant protein D. Respir Res 2006;7:85.

6 Lomas D, Silverman E, Edwards L, et al: Serum surfactant protein $\mathrm{D}$ is steroid sensitive and associated with exacerbation of COPD. Eur Respir J 2009;34:95-102.

7 Blann A, Nadar S, Lip G: The adhesion molecules P-selectin and cardiovascular disease. Eur Heart J 2003;24:2166-2179.

$>8$ Di Stefano A, Maestrelli P, Roggeri A, et al: Up-regulation of adhesion molecules in the bronchial mucosa of subjects with chronic obstructive bronchitis. Am J Respir Crit Care Med 1994;149:803-810.

$\checkmark 9$ Noguera A, Busquets X, Sauleda J, et al: Expression of adhesion molecules and G proteins in circulating neutrophils in chronic obstructive pulmonary disease. Am J Respir Crit Care Med 1998;158:1664-1668.
10 Gan W, Man S, Senthilselvan A, et al: Association between chronic obstructive pulmonary disease and system inflammation: a systemic review and a meta-analysis. Thorax 2004;59:574-580.

11 Hollander C, Sitkauskiene B, Sakalauskas R, et al: Serum and bronchial lavage fluid concentration of IL-8, SLPI, sCD14 and sICAM-1 in patients with COPD and asthma. Respir Med 2007;101:1947-1953.

12 Dentener M, Creutzberg E, Schols A: Systemic anti-inflammatory mediators in COPD: increase in soluble interleukin 1 receptor II during treatment of exacerbation. Thorax 2001; 56:721-726.

13 Kony S, Zureik M, Driss F, et al: Association of bronchial hyperresponsiveness and lung function with C-reactive protein (CRP): a population based study. Thorax 2004;59:892896.

14 Crouch E: Surfactant protein-D and pulmonary host defense. Respir Res 2000;1:93-108.

15 Adams D, Mainolfi E, Elias E, et al: Detection of circulating intercellular adhesion molecule-1 after liver transplantation - evidence of local release within the liver during graft rejection. Transplantation 1993;55:83-87.

16 Roberts WL, Sedrick R, Moulton L, et al: Evaluation of four automated high-sensitivity Creactive protein methods: implications for clinical and epidemiological applications. Clin Chem 2000;46:461-468.

17 LeVine AM, Whitsett JA, Gwozdz JA, et al: Distinct effects of surfactant protein A or D deficiency during bacterial infection on the lung. J Immunol 2000;165:3934-3940.

$>18$ Dahi M: Biomarkers for chronic obstructive pulmonary disease: surfactant protein $\mathrm{D}$ and C-reactive protein. Am J Respir Crit Care Med 2008;177:1177-1179.
19 Laniado-Laborin R: Smoking and chronic obstructive pulmonary disease (COPD): parallel epidemics of twenty first century. Int J Environ Res Public Health 2009;6:209-224.

20 Sin DD, Leung R, Gan WQ, et al: Circulating surfactant protein $\mathrm{D}$ as a potential lung-specific biomarker of health outcomes in COPD: a pilot study. BMC Pulm Med 2007;7:13.

21 Ju CR, Liu W, Chen RC: Serum surfactant protein D: biomarker of chronic obstructive pulmonary disease. Dis Markers 2012;32: 281-288.

22 Cazzola M, Novelli G: Biomarkers in COPD. Pulm Pharmacol Ther 2010;23:493-500.

23 Thyagarajan B, Smith LJ, Barr RG, et al: Association of circulating adhesion molecules with lung function: the CARDIA study. Chest 2009; 135:1481-1487.

24 Hopkinson NS, Tennant RC, Dayer MJ, et al: A prospective study of decline in fat free mass and skeletal muscle strength in chronic obstructive disease. Respir Res 2007;13:8-25.

25 Man SF, Connett JE, Anthonisen NR, et al: Creactive protein and mortality in mild to moderate chronic obstructive pulmonary disease. Thorax 2006;61:849-853.

26 Alavi SA, Soati F, Forghanparast K, et al: HsCRP in patients with acute exacerbation of chronic obstructive pulmonary disease. Iran Red Crescent Med J 2011;13:713-721.

27 Bircan A, Gokirmak M, Kilic O, et al: C-reactive protein levels in patients with chronic obstructive pulmonary disease: role of infection. Med Princ Pract 2008; 17:202-218.

28 Walter RE, Wilk JB, Larson MG, et al: Systemic inflammation and COPD: the Framingham Heart Study. Chest 2008;133:19-25. 